Supporting Information

\title{
Oxygen Coordination on Fe-N-C to Boost Oxygen Reduction Catalysis
}

Hangjia Shen ${ }^{\mathrm{a}}$, Hongjie Peng ${ }^{\mathrm{b}}$, Rui Cao ${ }^{\mathrm{c}}$, Liu Yang ${ }^{\mathrm{d}}$, Yan Gao ${ }^{\mathrm{e}}$, Ayse Turak, Tiju Thomas ${ }^{\mathrm{g}}$, Xuyun Guo ${ }^{\mathrm{h}}$, Ye Zhu ${ }^{\mathrm{h}}$, Jiacheng Wang ${ }^{\mathrm{ai}}$, Minghui Yang ${ }^{\mathrm{a} *}$ 


\section{Experimental section}

Chemicals. All chemicals were used as received without further purification. Tetraethyl orthosilicate (TEOS), thiourea, hydrochloric acid ( $\mathrm{HCl},>36 \%)$, hydrofluoric acid (HF, 40\%), sulfuric acid $\left(\mathrm{H}_{2} \mathrm{SO}_{4}, 98 \%\right)$, ethylenediamine (EDA), carbon tetrachloride (CTC), iron phthalocyanine (97\%) and ferric acetylacetonate were purchased from Aladdin (Shanghai, China). Triblock copolymer Pluronic P123 $\left(\mathrm{EO}_{20} \mathrm{PO}_{70} \mathrm{EO}_{20}\right.$, average $\left.\mathrm{Mn} \sim 5800, \mathrm{BASF}\right)$ and Nafion solution (5\%) were supplied by Sigma-Aldrich (Shanghai, China). Deionized water $(\geq 18.2 \mathrm{M} \Omega$ ) was used for the preparation of all aqueous solution. A commercial Pt/Vulcan (Pt loading 20\%, Premetek, US) sample labelled as Pt/C (20 wt $\%)$ was evaluated as benchmark for the activity comparison.

Catalyst Preparation. The ordered mesoporous silica (SBA-15) was synthesized in $2.0 \mathrm{M}$ $\mathrm{HCl}$ aqueous solution according to the method of Ding et al.[1] $1.0 \mathrm{~g}$ SBA-15 powder was added to a mixture of $2.7 \mathrm{~g}$ ethylenediamine (EDA), $6.0 \mathrm{~g}$ carbon tetrachloride (CTC), $0.2 \mathrm{~g}$ thiourea and $0.063 \mathrm{~g}$ ferric acetylacetonate. After sonication for $\sim 5 \mathrm{~min}$, the resultant uniform suspension was refluxed and stirred at $90{ }^{\circ} \mathrm{C}$ for $6 \mathrm{~h}$. Then, the obtained dark-brown composite was carbonized at $900{ }^{\circ} \mathrm{C}$ for $1 \mathrm{~h}$. This was done at a heating rate of $5{ }^{\circ} \mathrm{C} \mathrm{min}{ }^{-1}$,

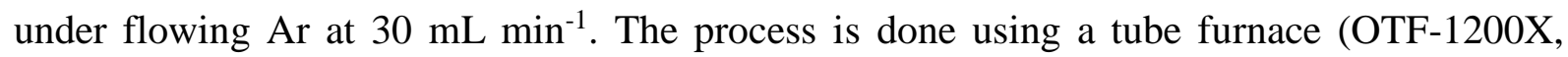
Hefei Kejing Materials Technology Co., Ltd). After carbonization, the template of silica framework was removed by $8 \mathrm{wt} \%$ hydrofluoric acid at $40{ }^{\circ} \mathrm{C}$ for $2 \mathrm{~h}$. Finally, the sample was successively washed several times with water and ethanol during filtration and dried at $110{ }^{\circ} \mathrm{C}$ for 6 h. The finally obtained product was designated as Fe-SNC-1. For comparison, catalysts Fe-SNC-2 or Fe-SNC-3 were prepared via the same procedure with $0.315 \mathrm{~g}$ or $0.63 \mathrm{~g}$ ferric acetylacetonate, respectively.

Characterization. Nitrogen sorption measurement was determined at $-196{ }^{\circ} \mathrm{C}$ using an Autosrob-iQ (Quantachrome INSTRUMENTS), and the pore size distributions were 
calculated by BJH method based on desorption branch. The X-ray diffraction (XRD) was conducted using a D8 ADVANCE DAVINCID (Bruker). The morphologies of the catalysts were characterized by aberration-corrected scanning transmission electron microscopy (AC-STEM) equipped with an energy dispersive X-ray spectrometer (EDS) on FEI Titan Cubed Themis G2 300. X-ray photoelectron spectroscopic (XPS) measurements were performed on a Kratos Axis Ultra DLD using $96 \mathrm{~W}$ Al Ka radiation, and the binding energies were referenced to the $\mathrm{C} 1 \mathrm{~s}$ line at $284.8 \mathrm{eV}$ from adventitious carbon. Before the inductively coupled plasma optical emission spectrometry (ICP-OES) test on SPECTRO ARCOS ${ }^{\mathrm{II}}$, the prepared sample were resolved by mixed acid $\left(\mathrm{H}_{2} \mathrm{SO}_{4}: \mathrm{HClO}_{4}: \mathrm{HNO}_{3}=6: 3: 2\right.$ in volume ratio $)$ and diluted by deionized water. X-ray Absorption Fine Structure (XAFS) was performed at the beam line 4W1B of Beijing Synchrotron Radiation Facility (BSRF). The storage rings of BSRF were operated at $2.5 \mathrm{GeV}$ with a maximum current of $250 \mathrm{~mA}$. EXAFS data were collected using a fixed-exit double-crystal Si (111) monochromator. Fe K edge EXAFS data were analyzed using standard procedures with the program IFEFFIT.

Electrochemical tests. Electrochemical measurements were all carried out on $\mathrm{CHI} 760 \mathrm{E}$ (Chenhua Instruments Co., Shanghai) without IR compensation. The catalysts inks (20 mg $\mathrm{mL}^{-1}$ for Fe-SNC-1, Fe-SNC-2 or Fe-SNC-3, and $10 \mathrm{mg} \mathrm{mL}^{-1}$ for $\mathrm{Pt} / \mathrm{C}$ ) were prepared by dispersing the catalyst in a mixture of water:isopropyl alcohol at volume ratio of 1:1 with 0.1 wt $\%$ Nafion as a binder. After sonicating for $30 \mathrm{~min}$, a uniform ink was obtained. $5 \mu \mathrm{L}$ of ink was deposited on the polished $5 \mathrm{~mm}$ glassy carbon electrode to fabricate the work electrode. All electrochemical measurements were carried out at room temperature $\left(18-20{ }^{\circ} \mathrm{C}\right)$ using a rotating disk electrode (RDE, Pine Instrument). The counter and reference electrodes were a graphite rod and $\mathrm{Ag} / \mathrm{AgCl}$ (saturated $\mathrm{KCl}$ aqueous solution), respectively. Cyclic voltammetry (CV) experiments were recorded at a sweep rate of $50 \mathrm{mV} \mathrm{s}^{-1}$, and the RDE polarization curves were recorded under various rotation rates at a scan rate of $10 \mathrm{mV} \mathrm{s}^{-1}$ and corrected for the background current measured in argon saturated electrolyte. Prior to CV and RDE tests, 
the electrolyte solution was bubbled with oxygen or argon for more than 20 min with a flowing rate of $100 \mathrm{~mL} / \mathrm{min}$. The durability of catalysts was evaluated by performing the chronoamperometric measurement in the $\mathrm{O}_{2}$-saturated solution at for $6000 \mathrm{~s}$. A certain amount of methanol $(0.5 \mathrm{M})$ was added to the electrolyte to evaluate the methanol tolerance of catalysts during chronoamperometric measurement. All the potentials reported in this work were converted to the RHE.

For the Tafel plot, the kinetic current was calculated from the mass-transport correction of RDE by:

$$
\mathrm{J}_{\mathrm{K}}=\frac{\mathrm{J} \times \mathrm{J}_{\mathrm{L}}}{\mathrm{J}_{\mathrm{L}}-\mathrm{J}}
$$

The calculation of electron transferred number for ORR via the RRDE measurement. The disk electrode was scanned cathodically at a rate of $10 \mathrm{mV} \mathrm{s}^{-1}$ and the ring potential was constant at $1.0 \mathrm{~V}$ versus $\mathrm{Ag} / \mathrm{AgCl}$. Hydrogen peroxide yields and the electron transfer number (n) were determined by the followed equations:

$$
\begin{aligned}
& \mathrm{H}_{2} \mathrm{O}_{2}(\%)=200 \times \frac{\left|\mathrm{J}_{\mathrm{R}} / \mathrm{N}\right|}{\left|\mathrm{J}_{\mathrm{D}}\right|+\left|\mathrm{J}_{\mathrm{R}} / \mathrm{N}\right|} \\
& \mathrm{n}=4 \times \frac{\left|\mathrm{J}_{\mathrm{D}}\right|}{\left|\mathrm{J}_{\mathrm{D}}\right|+\left|\mathrm{J}_{\mathrm{R}} / \mathrm{N}\right|}
\end{aligned}
$$

Where $J_{D}$ and $J_{R}$ is disk and ring current, respectively. $N$ is current collection efficiency of the $\mathrm{Pt}$ ring and the measured $\mathrm{N}$ value was $37 \%$.

\section{Computational details}

All DFT calculations were performed with the BP86 functional and in a spin-unrestricted formalism, allowing for broken-symmetry solutions, using the ORCA 3.0.3 program system.[2] In general, we used Ahlrich's all-electron triple-z triple polarization basis set TZVPP for Fe and TZVP for all other atoms.[3] Furthermore, tight SCF convergence criteria 
were employed throughout. The SlowConv criterion was employed and a SCF grid of 4 with no final grid was used. A higher grid (grid7) was used on the Fe atom as special grid atoms.

The routine associative ORR mechanism in acidic media was considered for calculating the adsorption energies of key intermediates. The reaction steps are shown as:

$$
\begin{aligned}
& \mathrm{O}_{2}+* \rightarrow \mathrm{O}_{2}^{*} \\
& \mathrm{O}_{2}^{*}+\mathrm{H}^{+}+\mathrm{e}^{-}+\rightarrow \mathrm{OOH}^{*} \\
& \mathrm{OOH}^{*}+\mathrm{H}^{+}+\mathrm{e}^{-} \rightarrow \mathrm{O}^{*}+\mathrm{H}_{2} \mathrm{O} \\
& \mathrm{O}^{*}+\mathrm{H}^{+}+\mathrm{e}^{-} \rightarrow \mathrm{OH}^{*} \\
& \mathrm{OH}^{*}+\mathrm{H}^{+}+\mathrm{e}^{-} \rightarrow \mathrm{H}_{2} \mathrm{O}
\end{aligned}
$$

where the $*$ represent the empty adsorption site on the catalyst.

In the series of $\mathrm{FeN}_{2} \mathrm{C}_{2}, \mathrm{O}_{2} *, \mathrm{OOH}^{*}, \mathrm{O}^{*}$, and $\mathrm{OH}^{*}$ were employed as the adsorbates for the benchmark electronic calculations. The same calculation methods were employed for the series of $\mathrm{O}-\mathrm{FeN}_{2} \mathrm{C}_{2}$ and $\mathrm{HO}-\mathrm{FeN}_{2} \mathrm{C}_{2}$ with $\mathrm{O}_{2}^{*}, \mathrm{OOH}^{*}, \mathrm{O}^{*}$, and $\mathrm{OH}^{*}$ as adsorbates, respectively. All the energies were referenced to gas-phase $\mathrm{H}_{2} \mathrm{O}(0.035$ bar, equilibrium fugacity for gas and liquid $\mathrm{H}_{2} \mathrm{O}$ at $298 \mathrm{~K}$ ) and $\mathrm{H}_{2}$ (1.0 bar, defined by the computational hydrogen electrode) and the method of computational hydrogen electrode was used to describe the potential dependence of reaction energies of steps that involve proton-electron transfer [4]. The electronic energies were further converted to free energies by adding the zero-point energy and entropy contributions using the harmonic approximation. Total free energy corrections were listed in Table $\mathrm{S} 4$ and the same as in the previous study by Patel et al. on similar copper-modified covalent triazine frameworks (Cu/CTF) single-atom catalysts.[5] In the same study, the authors have benchmarked the solvent effect on the adsorption energies and found that the solvation had more impact on single-atom catalytic materials than conventional transition metals due to the structural flexibility of the coordinated catalytic sites. Herein we employed the same solvation free energy corrections (listed in Table S4) as an estimation by assuming that the Fe-SNC materials have similar structural flexibility to 
$\mathrm{Cu} / \mathrm{CTF}$. Note that the total free energy difference for the full reaction $2 \mathrm{H}_{2}+\mathrm{O}_{2}=2 \mathrm{H}_{2} \mathrm{O}$ was taken from experiment as $2.46 \mathrm{eV}$ (equivalent to the equilibrium potential of $1.23 \mathrm{~V}$ ) to prevent a DFT calculation for the $\mathrm{O}_{2}$ molecule, of which the high-spin ground state is notoriously poorly described in DFT calculations.[6] Graphics of all molecular structure were created using the VESTA program.[7] 

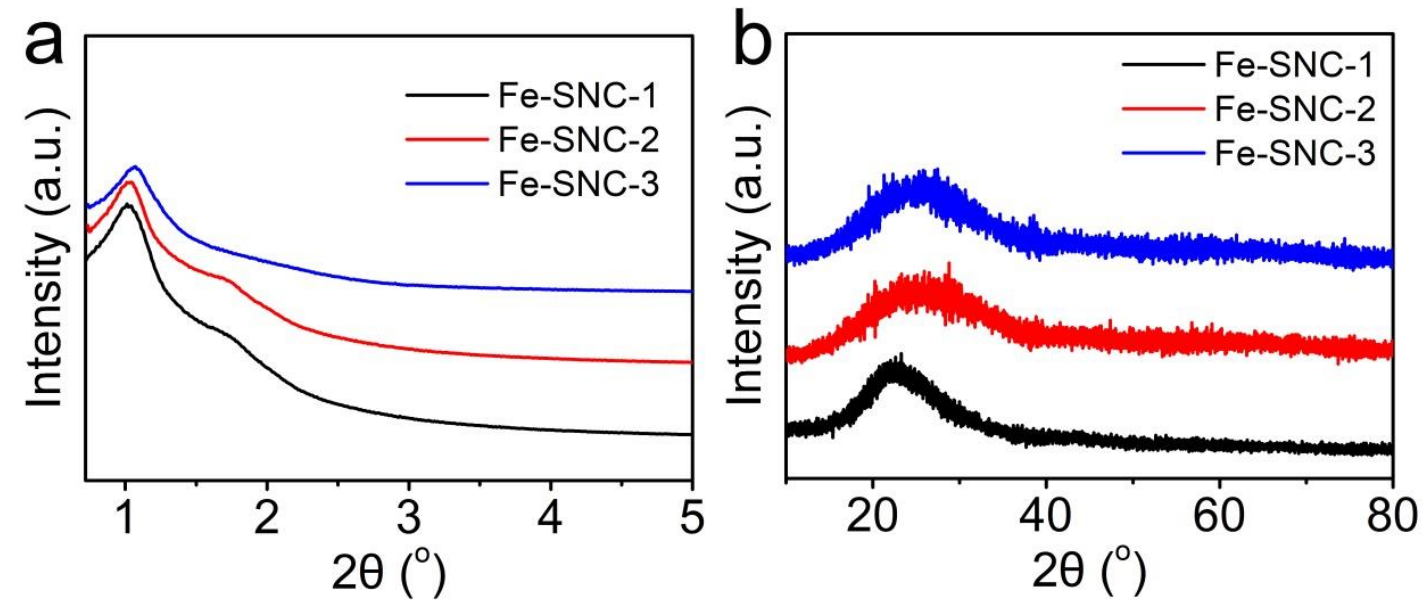

Figure S1. Small (a) and wide (b) angle X-ray diffraction patterns of Fe-SNC-1, Fe-SNC-2 and Fe-SNC-3.

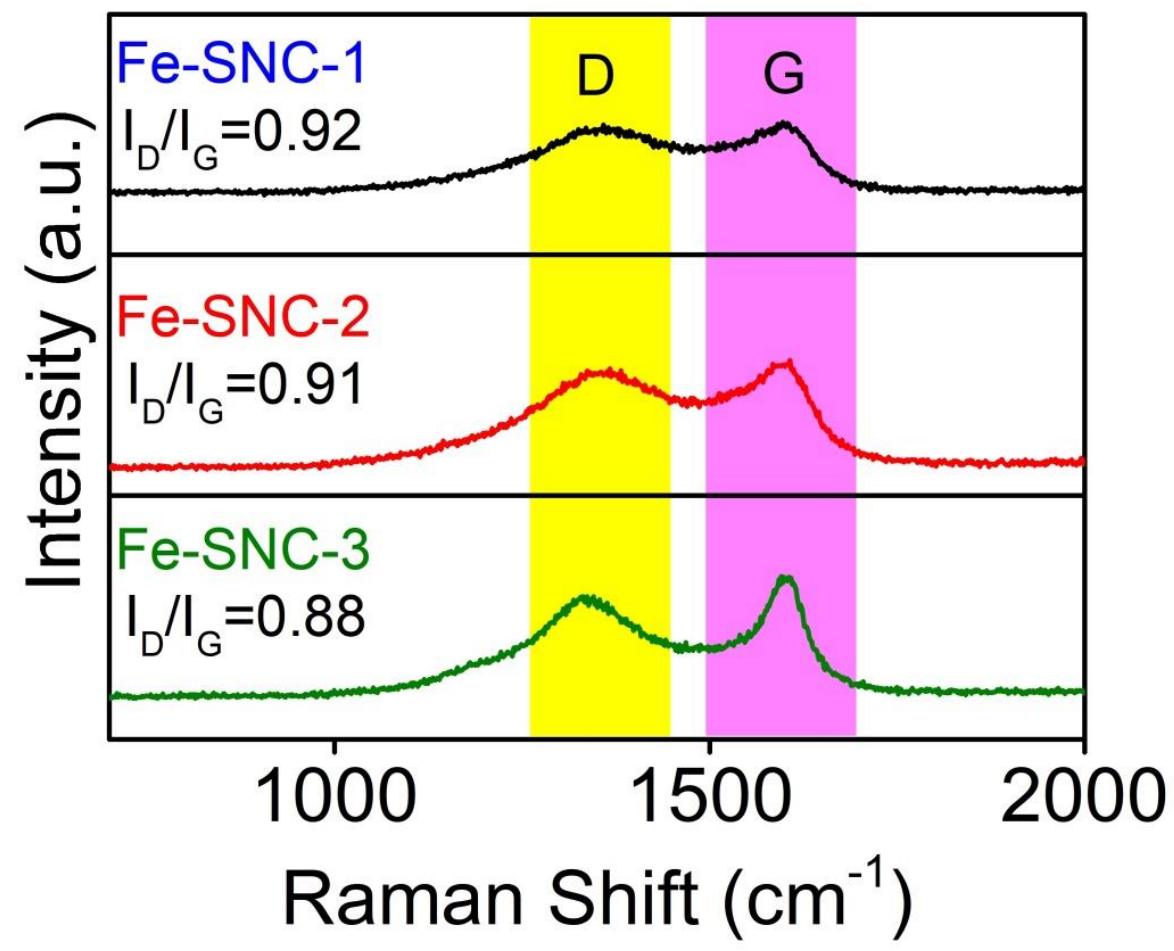

Figure S2. Raman spectra of Fe-SNC-1, Fe-SNC-2 and Fe-SNC-3. 

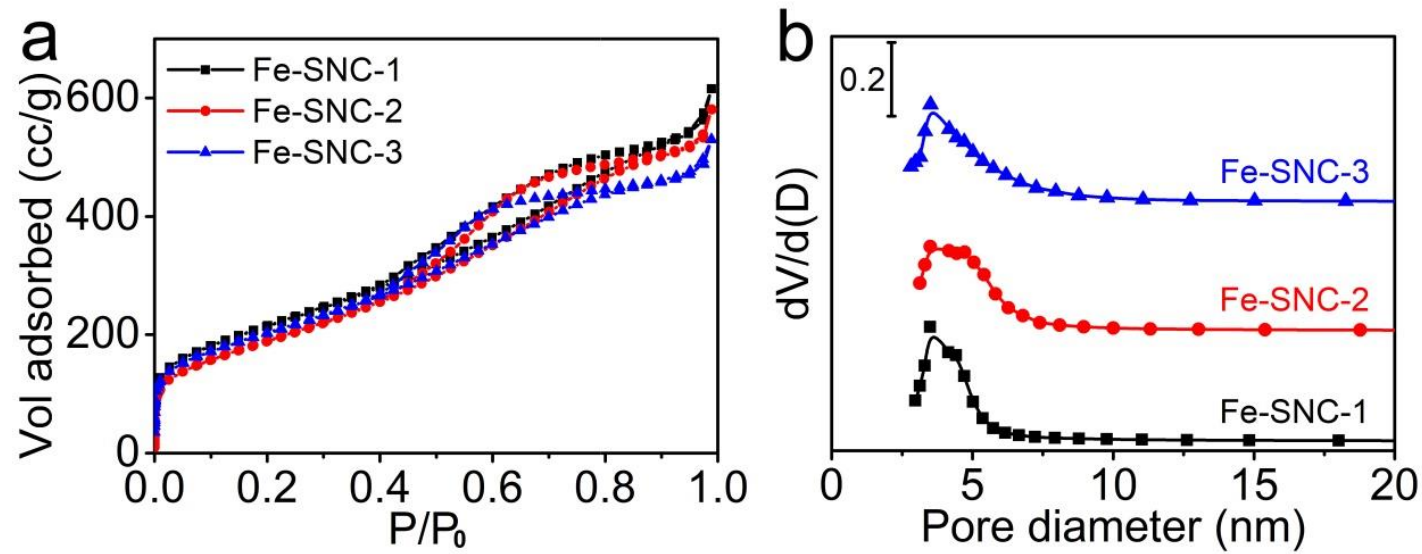

Figure S3. Nitrogen sorption isotherms (a) and pore size distribution (b) of Fe-SNC-1, Fe-SNC-2 and Fe-SNC-3.
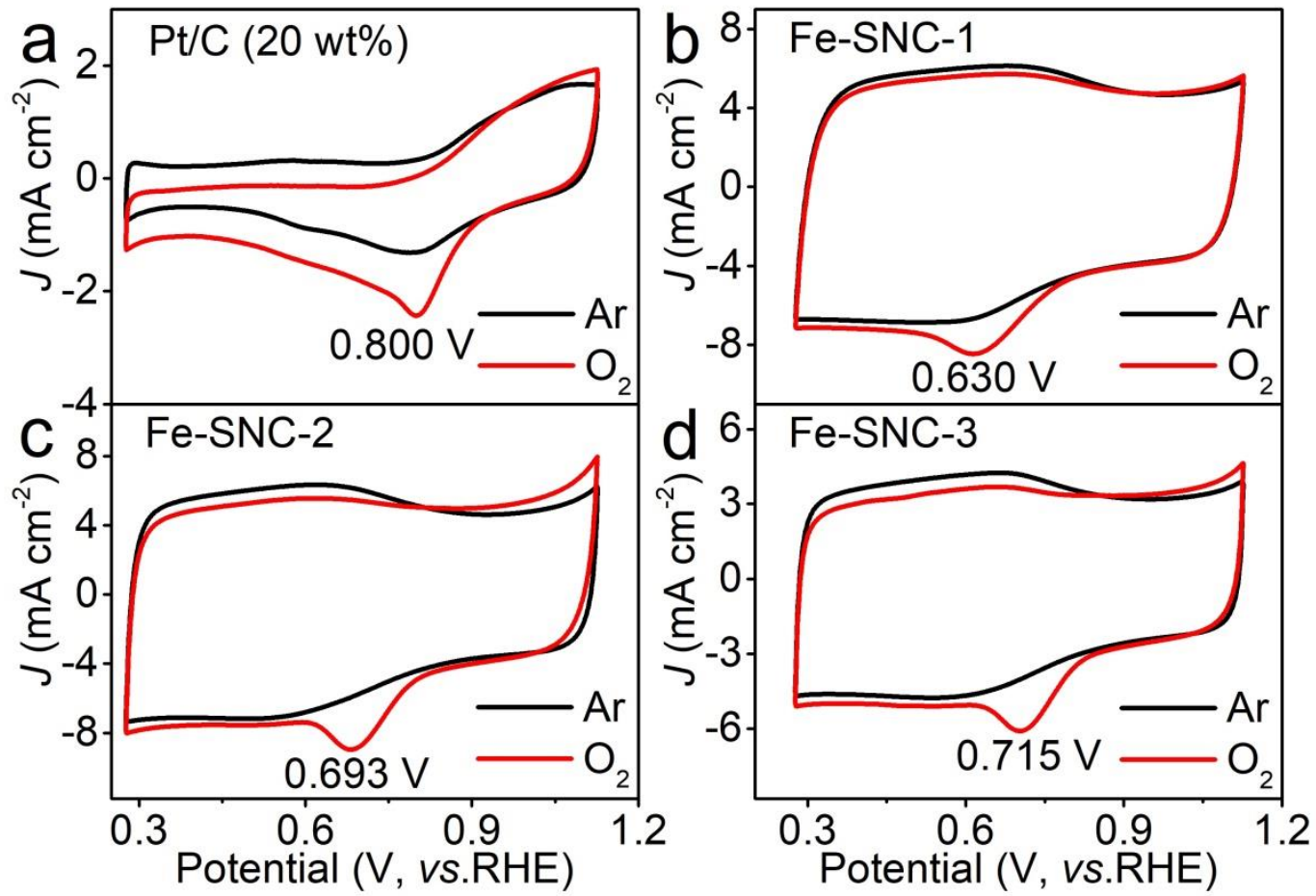

Figure S4. Cyclic voltammetry curves of catalysts in Ar- (black line) and $\mathrm{O}_{2}$ - (red line) saturated $0.5 \mathrm{M} \mathrm{H}_{2} \mathrm{SO}_{4}$ solution at a scan rate of $50 \mathrm{mV} \mathrm{s}^{-1}$. (a) $\mathrm{Pt} / \mathrm{C}(20 \mathrm{wt} \%)$; (b) Fe-SNC-1; (c) Fe-SNC-2 and (d) Fe-SNC-3. 

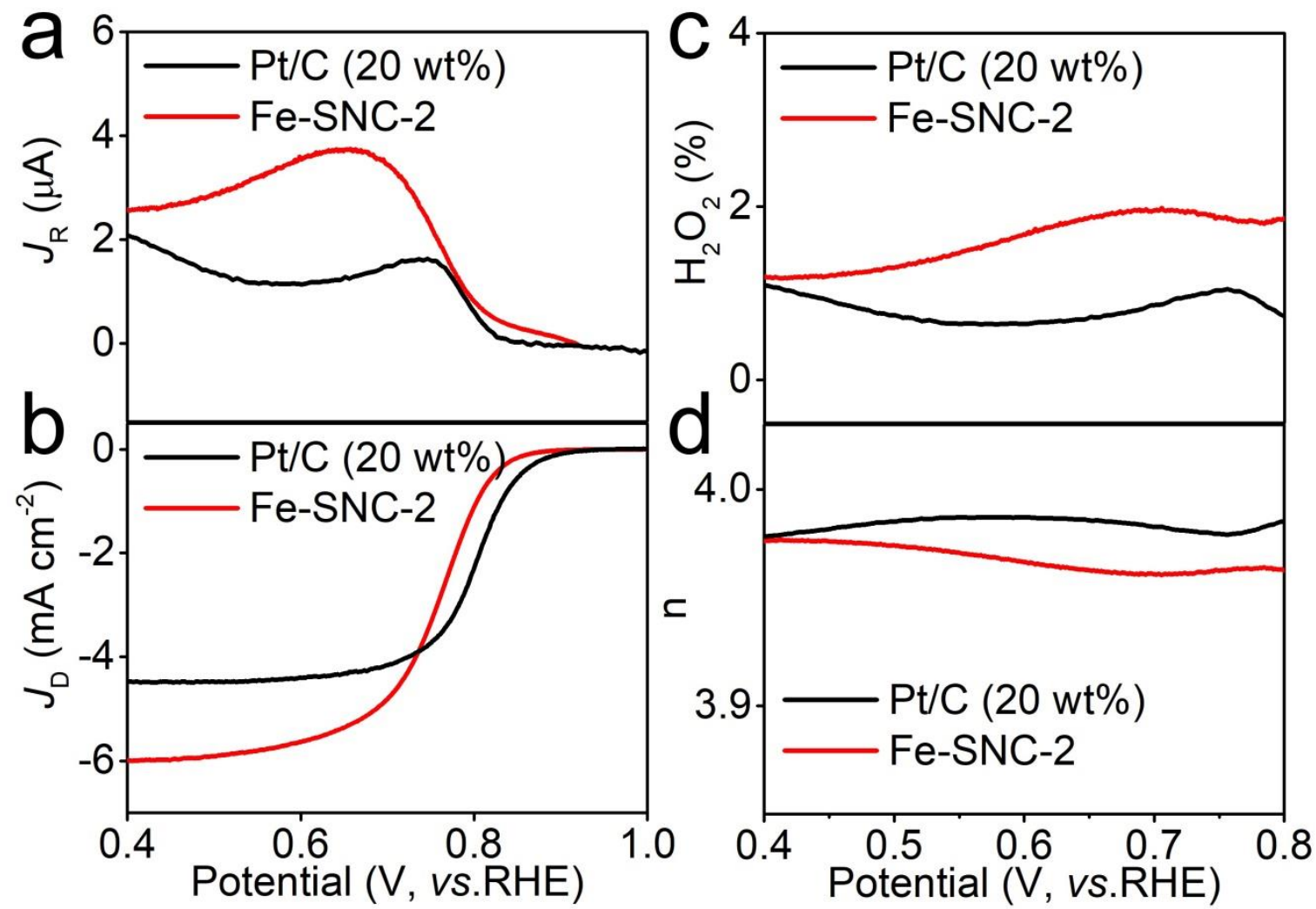

Figure S5. Rotating ring-disk electrode voltammograms of different catalysts in $\mathrm{O}_{2}$-saturated $0.5 \mathrm{M} \mathrm{H}_{2} \mathrm{SO}_{4}$ at $1600 \mathrm{rpm}$. (a) The ring current collected at potential of $1.0 \mathrm{~V}$ versus $\mathrm{Ag} / \mathrm{AgCl}$; (b) the disk current density scanned at $10 \mathrm{mV} \mathrm{s}^{-1}$; (c) the hydrogen peroxide yield and (d) the electron transfer number at various potentials based on the corresponding RRDE data.

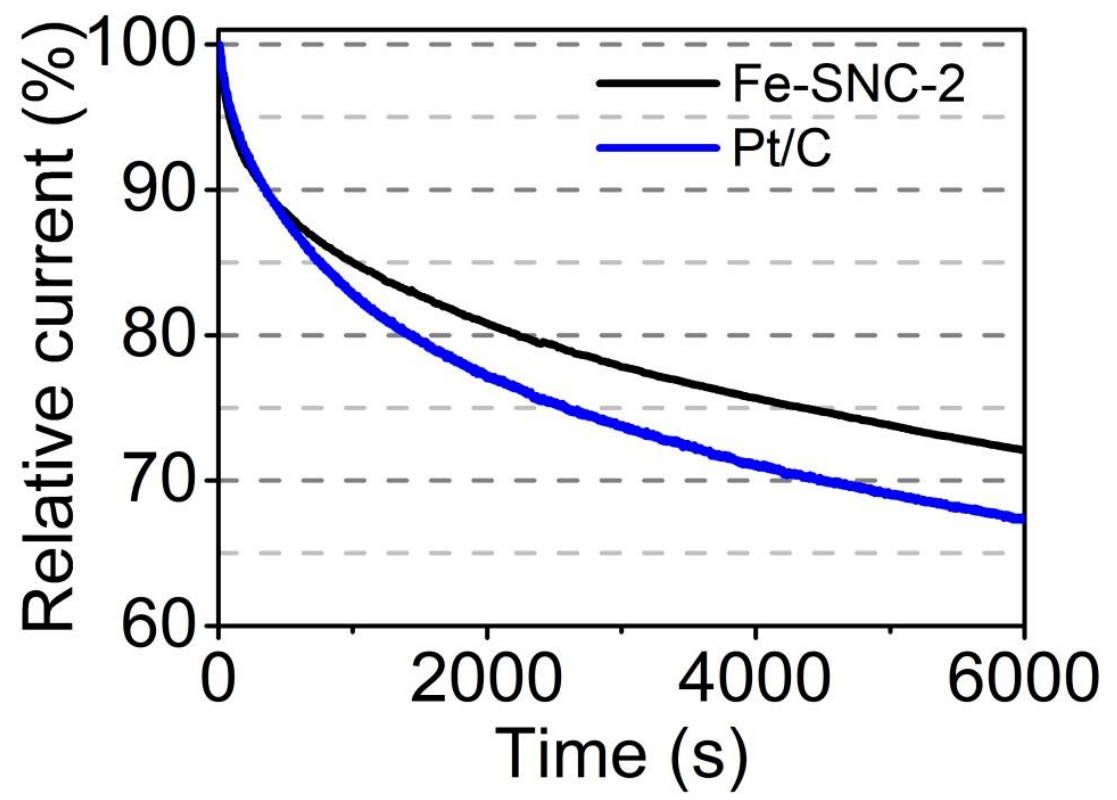

Figure S6. Chronoamperometric responses in $0.5 \mathrm{M} \mathrm{H}_{2} \mathrm{SO}_{4}$ of different catalysts. 

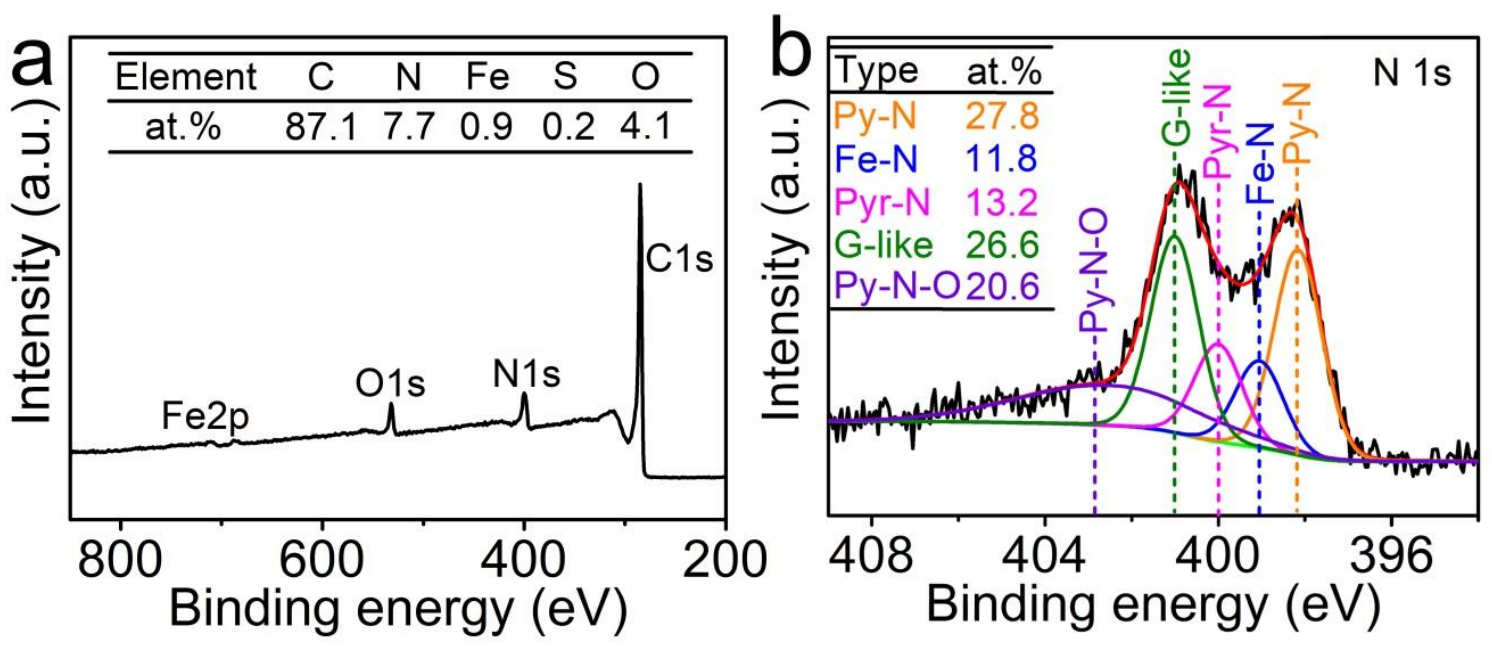

Figure S7. (a) The wide-range x-ray photoelectron spectra. (b) High resolution N 1s spectrum of Fe-SNC-2.

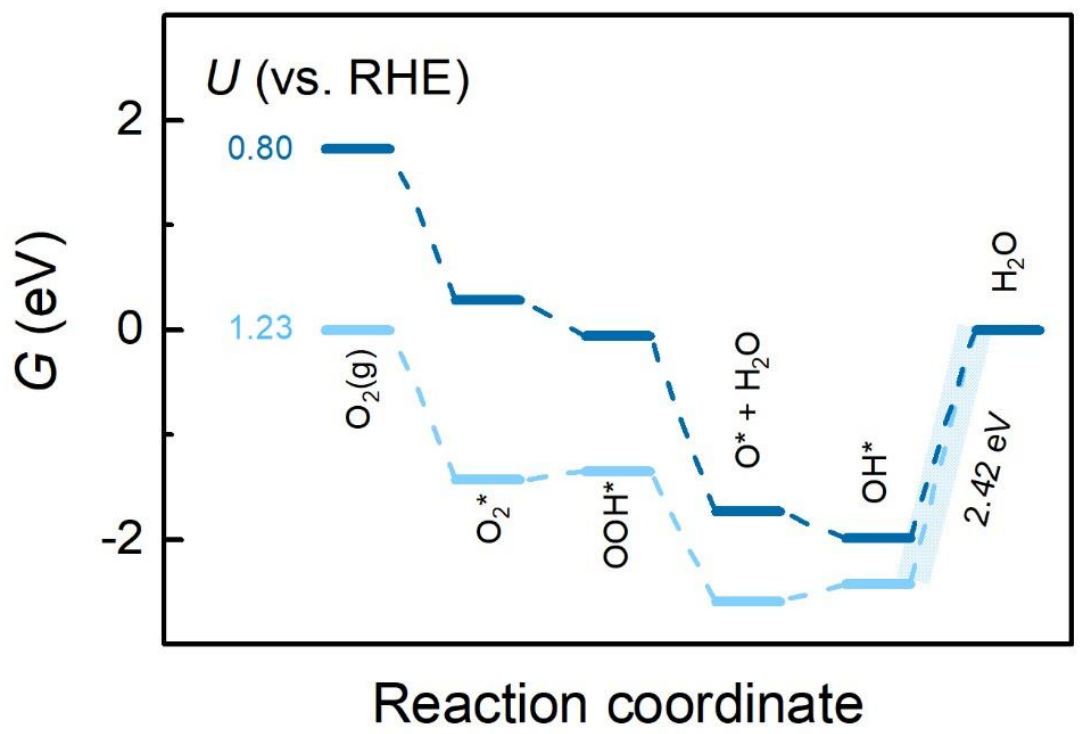

Figure S8. Free energy diagrams of ORR on the clean $\mathrm{Fe}-\mathrm{N}_{2} \mathrm{C}_{2}$ site at 1.23 and $0.80 \mathrm{~V}$ vs. RHE. 
Table S1. Textural properties of as-prepared materials.

\begin{tabular}{lccccccc}
\hline Catalysts & $\begin{array}{c}\text { Specific } \\
\text { surface } \\
\text { area } \\
\left(\mathrm{m}^{2} \mathrm{~g}^{-1}\right)\end{array}$ & $\begin{array}{c}\text { Micropor } \\
\text { e area } \\
\left(\mathrm{m}^{2}\right. \\
\left.\mathrm{g}^{-1}\right)\end{array}$ & $\begin{array}{c}\text { External } \\
\text { surfac } \\
\text { e area } \\
\left(\mathrm{m}^{2}\right. \\
\left.\mathrm{g}^{-1}\right)\end{array}$ & $\begin{array}{c}\text { Pore } \\
\text { volum } \\
\mathrm{e}\left(\mathrm{cm}^{3}\right. \\
\left.\mathrm{g}^{-1}\right)\end{array}$ & $\begin{array}{c}\text { Meso } \\
\text { por } \\
\text { osit } \\
\%\end{array}$ & $\begin{array}{c}\text { Pore } \\
\text { diam } \\
\text { eter } \\
(\mathrm{nm})\end{array}$ & $\begin{array}{c}\text { Fe } \\
\text { con } \\
\text { tent } \\
\text { a } \\
(\%)\end{array}$ \\
\hline $\begin{array}{c}\text { Fe-SNC- } \\
\quad\end{array}$ & 768 & 64 & 704 & 0.87 & 91.7 & 3.6 & 0.55 \\
$\begin{array}{c}\text { Fe-SNC- } \\
2\end{array}$ & 692 & 58 & 634 & 0.82 & 91.6 & 3.6 & 1.52 \\
$\begin{array}{c}\text { Fe-SNC- } \\
3\end{array}$ & 729 & 68 & 661 & 0.76 & 90.7 & 3.6 & 1.03 \\
\hline
\end{tabular}

${ }^{a}$ Determined by ICP-OES.

Table S2. Comparison of the performance of Fe-N-C materials for ORR in acidic medium.

\begin{tabular}{|c|c|c|c|c|c|c|c|c|}
\hline \multirow{2}{*}{ Samples } & \multirow{2}{*}{$\begin{array}{l}\text { Mass } \\
\text { loadin } \\
\mathrm{g}(\mathrm{mg} \\
\left.\mathrm{cm}^{-2}\right)\end{array}$} & \multirow{2}{*}{$\begin{array}{c}\text { Rotation } \\
\text { rate } \\
\text { (rpm) }\end{array}$} & \multirow{2}{*}{$\begin{array}{c}\mathrm{E}_{1 / 2} \\
(\mathrm{~V} \\
)\end{array}$} & \multirow{2}{*}{$\begin{array}{c}\mathrm{J}_{\mathrm{L}}(\mathrm{mA} \\
\mathrm{cm}^{-2} \\
)\end{array}$} & \multirow{2}{*}{$\begin{array}{c}\mathrm{J}_{\mathrm{K}} \text { at } 0.8 \\
\mathrm{~V} \\
(\mathrm{~mA} \\
\left.\mathrm{cm}^{-2}\right)\end{array}$} & \multicolumn{2}{|c|}{ Fe content } & \multirow{2}{*}{ Ref. } \\
\hline & & & & & & wt. $\%{ }^{\mathrm{c}}$ & at. $\%$ d & \\
\hline \multirow{3}{*}{$\mathrm{Fe}-\mathrm{SNC}-2^{\mathrm{a}}$} & & 900 & 0.80 & 4.2 & 4.2 & \multirow{3}{*}{1.52} & \multirow{3}{*}{0.90} & \multirow{3}{*}{$\begin{array}{l}\text { This } \\
\text { work }\end{array}$} \\
\hline & 0.5 & 1600 & 0.79 & 6.0 & 2.9 & & & \\
\hline & 1.0 & 1600 & 0.80 & 6.2 & 5.2 & & & \\
\hline $\mathrm{Fe} / \mathrm{SNC}^{\mathrm{a}}$ & 0.5 & 1600 & 0.77 & 4.6 & 0.8 & -- & 0.20 & \multirow{2}{*}[8]{} \\
\hline $\mathrm{Fe} / \mathrm{NC}^{\mathrm{a}}$ & 0.5 & 1600 & 0.74 & 4.7 & 0.3 & -- & 0.33 & \\
\hline $\mathrm{Fe} S A C / N-C^{b}$ & 0.3 & 1600 & 0.66 & 6.0 & 0.9 & -- & 1.50 & [9] \\
\hline Fe-N-C- $800^{b}$ & 0.61 & 1600 & 0.72 & 7.6 & 0.65 & & 0.24 & {$[10]$} \\
\hline Fe-N-GC- $900^{b}$ & 0.6 & 1600 & 0.74 & 5.3 & 0.8 & -- & 0.23 & [11] \\
\hline $\mathrm{FeNx} / \mathrm{GM}^{\mathrm{a}}$ & 0.6 & 900 & 0.80 & 4.2 & 3.8 & 0.18 & 0.15 & {$[12]$} \\
\hline $\mathrm{SA}-\mathrm{Fe} / \mathrm{NG}^{\mathrm{a}}$ & 0.6 & 1600 & 0.80 & 5.0 & 5.0 & & 0.6 & {$[13]$} \\
\hline $\mathrm{Fe}_{\mathrm{SA}}-\mathrm{N}-\mathrm{C}^{\mathrm{b}}$ & 0.28 & 1600 & 0.78 & 6.0 & 3.0 & 1.76 & -- & {$[14]$} \\
\hline $\begin{array}{l}\text { FeNx-NCNT-2- } \\
\mathrm{NH}_{3}{ }^{\mathrm{b}}\end{array}$ & 0.1 & 1600 & 0.68 & 6.0 & $\sim 1.2$ & 0.39 & -- & {$[15]$} \\
\hline $\begin{array}{c}1.0 \% \mathrm{Fe}-\mathrm{N}-\mathrm{GDY} \\
\mathrm{b}\end{array}$ & 0.61 & 1600 & 0.72 & 4.2 & -- & -- & 0.73 & {$[16]$} \\
\hline $\mathrm{Fe}-\mathrm{SAs} / \mathrm{NPSHC}$ & 0.5 & 1600 & 0.79 & 5.01 & 2.1 & 1.54 & -- & [17] \\
\hline $\mathrm{Fe}-\mathrm{N}-\mathrm{CC}^{\mathrm{a}}$ & 0.1 & 1600 & 0.62 & 3.5 & -- & -- & 0.2 & {$[18]$} \\
\hline $\mathrm{Fe}-\mathrm{N}-\mathrm{C}-1^{\mathrm{b}}$ & 0.5 & 1600 & 0.74 & 5.2 & 1.1 & 0.21 & & [19] \\
\hline $\mathrm{Fe} / \mathrm{S}-\mathrm{NC}^{\mathrm{a}}$ & 0.75 & 1600 & 0.76 & 4.3 & 1.3 & & 0.25 & [20] \\
\hline
\end{tabular}

${ }^{\mathrm{a}}$ Tested in $0.5 \mathrm{M} \mathrm{H}_{2} \mathrm{SO}_{4}$.

b Tested in $0.1 \mathrm{M} \mathrm{HClO}_{4}$.

${ }^{c}$ The total content detected by ICP.

d The surficial content detected by XPS. 
Table S3. Parameters of EXAFS fits for Fe-SNC-2 and iron phthalocyanine (FePc).

\begin{tabular}{cccccc}
\hline Sample & $\begin{array}{c}\text { Bond } \\
\text { type }\end{array}$ & $\begin{array}{c}\text { Coordination } \\
\text { Number }\end{array}$ & $\begin{array}{c}\text { Bond length } \\
\mathrm{R}(\AA)\end{array}$ & $\begin{array}{c}\text { Debye-Waller } \\
\text { factor } \sigma^{2}\left(\AA^{2}\right)\end{array}$ & R factor \\
\hline \multirow{3}{*}{ Fe-SNC-2 } & Fe-N & 2 & 1.87 & 0.007 & 0.007 \\
& Fe-O & 1 & 1.93 & 0.001 & 0.007 \\
& Fe-C & 2 & 2.11 & 0.004 & 0.007 \\
\hline \multirow{2}{*}{ FePc } & Fe-N & 4 & 1.92 & 0.003 & 0.01 \\
& Fe-C & 8 & 3.01 & 0.008 & 0.01 \\
& Fe-N & 4 & 3.40 & 0.011 & 0.01 \\
\hline
\end{tabular}

Fitting window $(\mathrm{R}): 1-4.1(\AA)$, amplitude reduction factor $\left(S_{0}^{2}\right): 0.9$ using fitting parameters from the Fe foil.

Table S4. Free energy corrections (ZPE-TS) and solvation corrections $\left(G_{\text {sol }}\right)$ used for theoretical modeling. $(T=298 \mathrm{~K})$

\begin{tabular}{lcccc}
\hline Adsorbate & $\mathrm{O}_{2}{ }^{*}$ & $\mathrm{OOH}^{*}$ & $\mathrm{O}^{*}$ & $\mathrm{OH}^{*}$ \\
\hline$Z P E-T S(\mathrm{eV})$ & 0.1 & 0.1 & 0.0 & 0.2 \\
$G_{\mathrm{sol}}(\mathrm{eV})$ & 0.0 & -0.35 & -0.55 & -0.65 \\
\hline$Z P E: Z e r 0-p$ & &
\end{tabular}

$Z P E$ : zero-point energy; $T$ : temperature; $S$ : entropy. These values are consistent with the previous study on single-atom catalysts.[21] 


\section{Supplementary References}

[1] Ding, Y.; Yin, G.; Liao, X. et al., A convenient route to synthesize SBA-15 rods with tunable pore length for lysozyme adsorption. Microporous Mesoporous Mater. 2013, 170, 45-51.

[2] Neese, F., The ORCA program system. Mol. Sci. 2012, 2 (1), 73-78.

[3] Weigend, F.; Ahlrichs, R., Balanced basis sets of split valence, triple zeta valence and quadruple zeta valence quality for $\mathrm{H}$ to $\mathrm{Rn}$ : Design and assessment of accuracy. Phys. Chem. Chem. Phys. 2005, 7 (18), 3297-3305.

[4] Norskov, J. K.; Rossmeisl, J.; Logadottir, A.; Lindqvist, L.; Kitchin, J. R.; Bligaard, T.; Jonsson, H., Origin of the overpotential for oxygen reduction at a fuel-cell cathode. $J$. Phys. Chem. B 2004, 108 (46), 17886-17892.

[5] Patel, A. M.; Ringe, S.; Siahrostami, S.; Bajdich, M.; Norskov, J. K.; Kulkarni, A. R., Theoretical Approaches to Describing the Oxygen Reduction Reaction Activity of Single-Atom Catalysts. J. Phys. Chem. C 2018, 122 (51), 29307-29318.

[6] Jones, R. O.; Gunnarsson, O., The density functiona formalism, its applications and prospects. Rev. Mod. Phys. 1989, 61 (3), 689-746.

[7] Momma, K.; Izumi, F., VESTA 3 for three-dimensional visualization of crystal, volumetric and morphology data. J.Appl. Crystallogr. 2011, 44, 1272-1276.

[8] Shen, H. et al. Synergistic Effects between Atomically Dispersed $\mathrm{Fe}-\mathrm{N}-\mathrm{C}$ and $\mathrm{C}-\mathrm{S}-\mathrm{C}$ for the Oxygen Reduction Reaction in Acidic Media. Angew. Chem. Int. Ed. 2017, 129, 13988-13992.

[9] Lin, Y. et al. Fabricating Single-Atom Catalysts from Chelating Metal in Open Frameworks. Adv. Mater. 2019, 31, 1808193.

[10]Wang, D. et al. Dual-nitrogen-source engineered Fe-Nx moieties as a booster for oxygen electroreduction. J. Mater. Chem. A 2019, 7, 11007-11015.

[11]Kong, A. et al. Ordered Hierarchically Micro- and Mesoporous Fe-Nx-Embedded Graphitic Architectures as Efficient Electrocatalysts for Oxygen Reduction Reaction. ACS Catal. 2014, 4, 1793-1800.

[12] Fu, X. et al. Tailoring $\mathrm{FeN}_{4}$ Sites with Edge Enrichment for Boosted Oxygen Reduction Performance in Proton Exchange Membrane Fuel Cell. Adv. Energy Mater. 2019, 9, 1803737.

[13] Yang, L. et al. Unveiling the high-activity origin of single-atom iron catalysts for oxygen reduction reaction. PNAS 2018, 115, 6626-6631. 
[14]Long, J. et al. From Metal-Organic Frameworks to Single-Atom Fe Implanted N-doped Porous Carbons: Efficient Oxygen Reduction in Both Alkaline and Acidic Media. Angew. Chem. Int. Ed 2018, 57, 8525-8529.

[15]Li, Y., Huang, H., Chen, S., Wang, C. \& Ma, T. Nanowire-Templated Synthesis of FeNx-Decorated Carbon Nanotubes as Highly Efficient, Universal-pH, Oxygen Reduction Reaction Catalysts. Chem.-Eur. J. 2019, 25, 2637-2644.

[16]Si, W. et al. Fe,N-Codoped Graphdiyne Displaying Efficient Oxygen Reduction Reaction Activity. ChemSusChem 2019, 12, 173-178.

[17]Chen, Y. et al. Enhanced oxygen reduction with single-atomic-site iron catalysts for a zinc-air battery and hydrogenair fuel cell. Nat. Commun. 2018, 9, 5422.

[18]Ferrero, G. A. et al. Fe-N-Doped Carbon Capsules with Outstanding Electrochemical Performance and Stability for the Oxygen Reduction Reaction in Both Acid and Alkaline Conditions. ACS Nano 2016, 10, 5922-5932.

[19]Liu, D. \& Long, Y.-T. Superior Catalytic Activity of Electrochemically Reduced Graphene Oxide Supported Iron Phthalocyanines toward Oxygen Reduction Reaction. ACS Appl. Mater. Inter. 2015, 7, 24063-24068.

[20]Zhang, P. et al. Fe and S co-doped N-enriched hierarchical porous carbon polyhedron as efficient non-noble-metal electrocatalyst toward oxygen reduction reaction in both alkaline and acidic medium. Electrochim. Acta 2019, 298, 570-579.

[21]Patel, A. M.; Ringe, S.; Siahrostami, S.; Bajdich, M.; Nørskov, J. K.; Kulkarni, A. R., Theoretical Approaches to Describing the Oxygen Reduction Reaction Activity of Single-Atom Catalysts. J. Phys. Chem. C 2018, 122, 29307-29318. 